Revista Brasileira de Ensino de Fúsica, v. 29, n. 4, p. 485-486, (2007)

www.sbfisica.org.br

\title{
Editorial
}

\section{Um tributo a William Thomson no centenário de sua morte}

2007 é o ano do centenário da morte de William Thomson, o proeminente físico britânico alçado à nobreza como Lorde Kelvin e que se tornou um ícone do establishment científico e tecnológico da era vitoriana. Na celebração dos 100 anos de seu nascimento em 1924 Sir J.J. Thomson, presidente da Royal Society, assim se manifestou: "Comemoramos hoje a memória de alguém a quem a ciência britânica deve muito de seu prestígio, e que por seus métodos próprios ampliou de modo amplo e importante nosso conhecimento, que é uma figura sobressalente na junção da teoria e da prática, e que nos deixou um exemplo de devoção persistente e incansável a um grandioso ideal".

A RBEF com sua política editorial de reverenciar grandes vultos que deram contribuições significativas ao desenvolvimento da física traz nesta edição uma seção especial em homenagem a Lorde Kelvin. Foram traduzidos dois artigos originais de Kelvin sobre a emergente ciência da termodinâmica, acompanhados de uma análise detalhada e contextualizada feita pela historiadora Penha Maria Cardoso Dias.

Embora seus trabalhos científicos mais conhecidos tenham sido em termodinâmica, Thomson deu várias contribuições importantes à física matemática nas grandes áreas de dinâmica geral, hidrodinâmica, elasticidade e eletromagnetismo. Em particular, contribuiu para o avanço de uma ampla gama de assuntos: a eletrostática (criou o método de imagens para citar um problema conhecido nas disciplinas de eletromagnetismo), eletrificação do ar, dinâmica de sólidos e líquidos, movimento ondulatório em sólidos elásticos, propagação de ondas na água, movimento de vórtices, e comportamento peculiar de cristais. Publicou um trabalho seminal sobre oscilações de correntes elétricas que constituiu a base teórica da telegrafia sem fio e radiotransmissão.

Além de cientista renomado, Thomson aplicou idéias e métodos científicos à indústria vencendo o preconceito e a improvisação no meio. Neste sentido foi um inovador na área tecnológica, um engenheiro renomado e um empreendedor bem sucedido. Suas notáveis contribuições ao progresso tecnológico podem ser agrupadas em três segmentos: telegrafia por cabo submarino no Atlântico; a precisão das medidas elétricas; e a arte da navegação.

No que se refere ao ensino, Thomson não poderia ser considerado um "bom professor" avaliado pelos padrões normais. Seus biógrafos apontam que, como professor, Thomson digressionava dos temas centrais, absorvido em idéias e soluções para problemas originais deixando os alunos irritados e desmotivados. Um dos seus estudantes escreveu: "o mérito de Lorde Kelvin como educador não está na elucidação de fatos bem conhecidos, mas na influência espiritual de sua personalidade magnética". Thomson foi o primeiro cientista a introduzir o laboratório didático em universidades britânicas. Mais tarde escreveu: "quando assumi a cátedra de Filosofia Natural em Glasgow não havia infra-estrutura para qualquer tipo de pesquisa experimental, muito menos algo para um trabalho prático dos estudantes." Nos primeiros anos conseguiu montar equipamentos para que as aulas fossem melhor ilustradas pelos experimentos. Alguns aparatos para o ensino desenvolvidos por Thomson são apresentados por J.T. Lloyd em artigo originalmente publicado em The Physics Teacher. Thomson escreveu ainda com P.G. Tait o livro Tratado de Filosofia Natural, um ambicioso projeto concebido para abarcar todo o conhecimento científico até então produzido. Tornaram-se famosas suas Palestras de Baltimore e Popular Lectures.

William Thomson foi um cientista criativo, polêmico e muito influente na comunidade britânica. Suas participações nas reuniões da British Association for Advancement of Science e outros encontros científicos eram precedidas de grande expectativa. Novas idéias e propostas, como as de J.P. Joule e as de M. Faraday, foram acolhidas por Thomson com entusiasmo e posteriormente desenvolvidas em trabalhos essenciais ao desenvolvimento da física no século XIX. Foi extremamente conservador em relação a alguns avanços da ciência como a teoria eletromagnética de Maxwell (apesar de suas idéias terem inicialmente inspirado Maxwell) e a radioatividade. Duvidava da existência de átomos e acreditava que a Terra não

Copyright by the Sociedade Brasileira de Física. Printed in Brazil. 
poderia ter mais do que cem milhões de anos, posicionando-se contra a teoria de Darwin. Manifestou-se cético com relação ao vôo do "mais-pesado-do-que-o ar".

A Lorde Kelvin são atribuídas muitas frases e aforismos que, na maioria das vezes, aparecem descontextualizadas ou nunca chegaram a ser pronunciadas. Duas delas "Não existe nada novo a ser descoberto em física agora [fins do século XIX]; tudo que resta é [fazer] medição mais e mais precisa" e "No céu azul da física clássica existem apenas duas nuvens a serem dirimidas...". São citações muito difundidas que preconizariam o "fim da física". Peter Schulz interpreta em um instigante artigo o contexto em que frases deste tipo se inserem na obra de Kelvin.

Sua contribuição à telegrafia se deu através do desenvolvimento dos componentes e instrumentos de medida e da instalação de cabos submarinos, em geral com sua presença física. Em 8 de agosto de 1897, Kelvin enviou carta do Recife onde afirma: "Esperamos ao entardecer de hoje zarpar rumo ao Pará, arreando cabo da popa do Hoover. Comprei um papagaio verde com asas de penas azul-escuro e esplendidas pontas vermelhas, cabeça branca e azulada e peito de um amarelo brilhante". ${ }^{1}$ Sua viagem ao Brasil, uma das muitas que realizou em todo o mundo como empresário bem sucedido, tinha a finalidade de puxar o cabo telegráfico submarino de Recife a Natal. Parte desta história, a visita a Belém do Pará, é narrada por José Maria Bassalo e Luis Carlos Crispino. Os debates de Kelvin com a comissão brasileira chefiada pelo Barão de Capanema, ${ }^{2}$ responsável pela instalação da primeira linha telegráfica no Brasil, sobre a viabilidade da passagem do cabo por São Luis serão apresentados em outro número da RBEF.

William Thomson nasceu em 26 de junho de 1824 em Belfast. Foi aluno em Cambridge e ocupou durante toda sua vida a cátedra de Filosofia Natural da Universidade de Glasgow que assumiu aos 22 anos de idade. Faleceu em dezembro de 1907 sendo enterrado na catedral de Westminster junto ao túmulo de Isaac Newton. Ao contrário de Newton, seu nome sobrevive, para o público em geral, apenas na escala de temperatura absoluta. ${ }^{3}$

Nelson Studart Departamento de Física Universidade Federal de São Carlos

\footnotetext{
${ }^{1}$ Segundo seu primeiro biógrafo Silvanus P. Thompson (1910), o Professor Papagaio, como ficou conhecido, viveu por muitos anos no College House. Quando morreu foi empalhado e exposto no Hunterian Museum da Universidade de Glasgow. Uma consulta recente ao Museu sobre o paradeiro do souvenir brasileiro de Kelvin foi encaminhada. Não houve resposta.

${ }^{2}$ I. de C. Moreira e M da C. Silva, Física na Escola 2(2) 31 (2001).

${ }^{3}$ Para ler mais: Lorde Kelvin no Dicionário de Biografias Científicas, v. 2, p. 1297, (Contraponto, Rio de Janeiro, 2007). Há uma biografia monumental Energy and Empire por Crosbie Smith e Norton Wise (1989). Outra boa biografia, mais acessível a um público menos especializado, é Degrees Kelvin, por David Lindley (2004). Há vários sítios na Internet que trazem artigos originais e ensaios sobre sua vida e obra.
} 